\title{
Sete Fontes: a Challenge to Promote the Heritage Legacy andFacing Water Sources Scarcity in the city of Braga-Portugal
}

\author{
JMP Vieira*, AALS Duarte* and PJ Ramisio \\ Department of Civil Engineering, University of Minho, Portugal
}

Received: 畊 April 16, 2018; Published: 非 April 20, 2018

*Corresponding author: JMP Vieira and António Sampaio Duart, Department of Civil Engineering, University of Minho, Campus de Gualtar, 4710-057 Braga, Portugal,Email: jvieira@civil.uminho.pt; aduarte@civil.uminho.pt

\begin{abstract}
An ancient drinking water supply system, called Sete Fontes (Seven Springs), was built in the mid eighteenth century in the city of Braga. The system is composed by underground galleries, cisterns, waterspouts, fountains, and (covered) stone aqueduct channels with about $3500 \mathrm{~m}$ long. This national monument, still existing and active, preserves both the original memorial role (representative of a boost to urban and baroque architecture), and the original function(improvement of quality of life), being a witness of the evolution of hydraulic engineering concepts, which greatly contributed to the improvement of urban infrastructures and the protection of public health. This paper also presents an overview of the history of the water supply system of the city of Braga, from the Roman period to the contemporary age, with special focus on Sete Fontes water sources characterization (morphological, hydrogeological, hydraulic, and water quality). This heritage legacy is invaluable not only for its history and cultural significance, while maintaining its authenticity and integrity, but also due to its confirmed water quality that can be an added value, taking a new relevance to address future scarcity scenarios of safe water sources in a climate change context.
\end{abstract}

\section{Introduction}

Drinking water supply; cultural heritage; safe water; Sete Fontes water sources; Braga. Drinking Water Supply from Bracara Augusta to Braga Water supply systems are essential for human quality of live and the sustainability of the urban environment. For these reasons, they were object of special attention in many civilizations. Different conceptual and operational solutions have been used over the centuries, depending on the knowledge and the technical means available in each of those periods. The close relationship of water supply systems and the morphology of ancient cities indicate that they strongly constrain their urban development, namely due to the availability and location of water sources with unquestionable quality and the possibility of gravity transport to the consumers. The urban sprawl of Braga throughout their ancestral occupational history, from the foundation of the Roman city of Bracara Augusta (1st century BC), confirms this trend, when the key urban transformations (road network, urban topology, built environment, land use) are careful analyzed. The city of Braga is located in the region of higher rainfall in Portugal and the most extensive hydrographic network (Cávado and Ave river basins).
The close presence of the river Este (south) and some others streams were determining factors for the genesis of its territorial occupation. The occupational longevity of Braga strengthens the relevance of performing regressive and multidisciplinary analysis to the urban space structure and, consequently, to this ancient water supply system (Ribeiro and Martins [1]).

\section{Roman Period}

Archaeological excavations in the urban area of Braga found some pre Roman water exploitation and use, like the sanctuary Fonte do Ídolo (Idol Fountain), dedicated to Tongoenabiago, a river divinity (Garrido et al. [2]), and the bathhouse of Bracara, that was located $300 \mathrm{~m}$ from the (future) wall of the Roman city of Bracara Augusta (Figure 1), where today is situated the new Braga railway station. Other archaeological excavations allowed identifying important traces of the Roman city that witness several aspects related to the ancestral drinking water and sanitation systems in Bracara Augusta, namely the Roman Baths of Maximinos (Figure 2). This system was built in the late first century (Flavian period), subsisting traces of four hot rooms whose hypocausts are 
relatively well preserved. There is still much uncertainty, for this period, about the location of water sources and its abstraction points, either within the city or in the outskirts of the urban center (Carvalho and Ribeiro [3]). It is only known that some of the Roman aqueducts that transported water to the town have remained active, although without proper maintenance, which led to their collapse in the early Middle Age, explaining some water shortage and public health problems in the city, often referenced in the historical documentation (Martins and Ribeiro [4]).

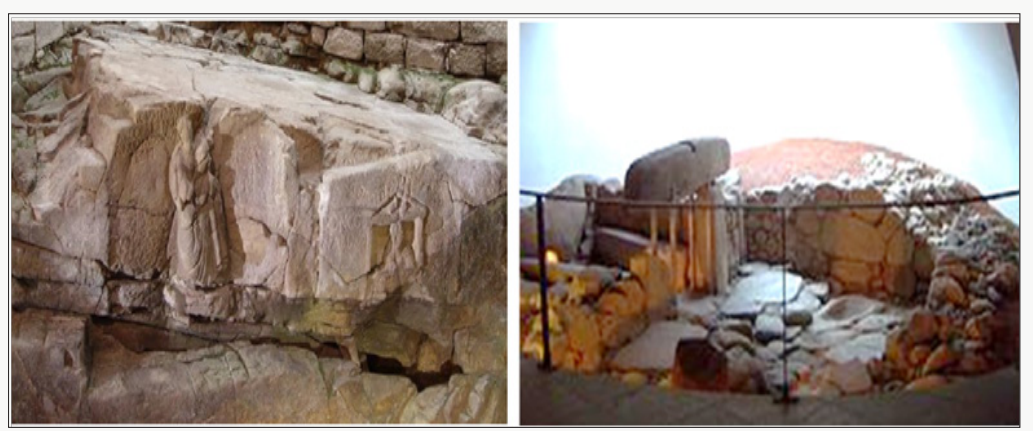

Figure 1: Pre Roman sanctuary of Fonte does Ídolo (left); pre-Roman bathhouse of Bracara (right) (source: Municipality of Braga).

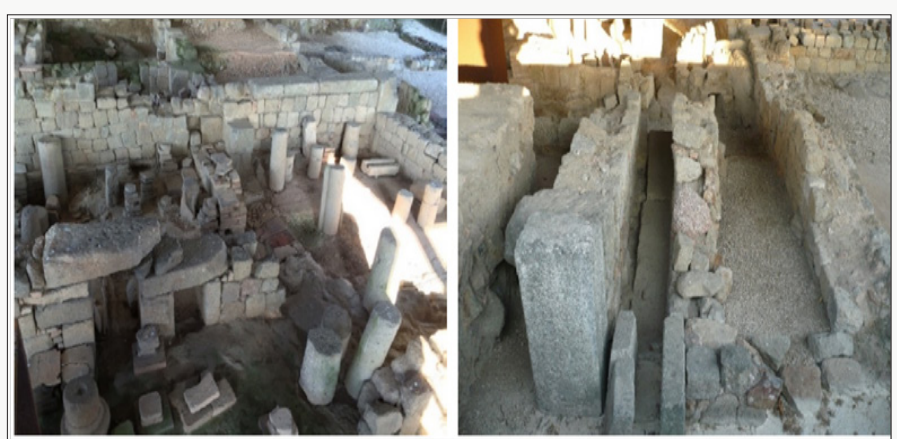

Figure 2: Details of the Roman Baths of Maximinos (source: Municipality of Braga).

\section{Middle Age}

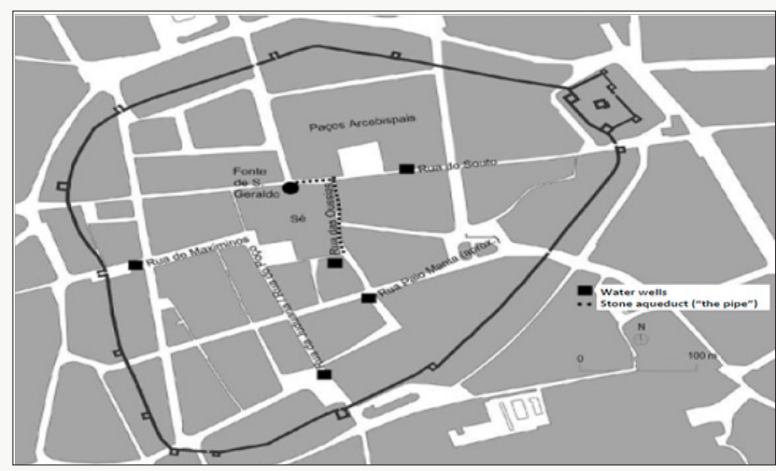

Figure 3: Location of the major hydraulic infrastructures for water supply of the medieval city of Braga (Adapted from Ribeiro and Martins [4]).

Considering the size of the city in the High Middle Ages, the intramural drinking water system should have been almost exclusively dependent on wells. Some medieval documents reveal not only the concerns to improve the water abstraction capacity (looking up to new sources or returning to some already existing), but also real difficulties to face water demand increase in the urban centre, Due to the Braga city's growth in the 14th century that implied the boundary enlargement of medieval rampart.
Documents of the fourteenth and fifteenth centuries refer several hydraulic infrastructures existing inside the rampart: nine wells (in six central streets), one stone aqueduct ("the pipe") and the (underground) Fonte de S. Geraldo (St. Gerard Fountain), with the locations shown in (Figure 3) One of these public wells (the southern one) remained operational until the 19th century and has constituted one of the most important sources of drinking water in the medieval town (Figure 3). Location of the major hydraulic 
infrastructures for water supply of the medieval city of Braga (adapted from Ribeiro and Martins [1]). The most interesting mention on historical documents, about the medieval water supply system (late 14th century) is about this protagonist "pipe" (of unknown origin, but with records on their restoration and enhancements woks), which was even used as a reference for some of the major city streets. This stone aqueduct flanked the head of Braga Cathedral, near the Archiepiscopal Palace, aiming to supply the most important part of the medieval city (its religious centre), perhaps through the Fonte de S Geraldo (Fountain of St. Gerard), and probably, in the Roman period, supplying a market (macellum), which would have required a large quantity of water (Fontes et al. [5]).

From the second quarter of the 15th century these water sources (within the walls) demonstrated to be insufficient to meet the increasing water demand. Therefore, it was necessary to reactivate old or find new sources (e.g., Monteariol, Sete Fontes, Gualtar) on the outskirts north of the city but less than a land league (about 5km) away (Figure 4). From there sources, the water would be transported by covered stone aqueducts till the medieval city from where it should be distributed by different devices, like fountains, waterspouts, tanks, and washtubs (Marques [6]). Some of these aqueducts would probably be from the Roman period, as there are traces of them along the major Roman roads (Carvalho and Ribeiro [3]), like Via XVIII (linking Bracara Augusta to Asturica Augusta Astorga) or the Via XVII (linking Bracara Augusta to Aquae Flaviae Chaves). Since ancient times, it was extremely important to ensure that water abstracted in remote areas could reach a main reservoir (called "matrix"), from which water could then be distributed to different strategic distribution points within the city. For example, the Romans used a water reservoir (castellum aquae or castellum divisorium) that received water from aqueducts and then distributed to fountains and bathhouses covering different areas of the city. So, it is quite likely that a roman castellum aquae could be in service in Bracara Augusta on the same location where in more recent times the main water reservoir of Braga, called Caixa Geral das Águas (Figure 4), near the city walls, has been referenced. This main reservoir was a stone structure, located near the medieval rampart, which had in its interior a great arch for water entrance, perhaps to perform water aeration.

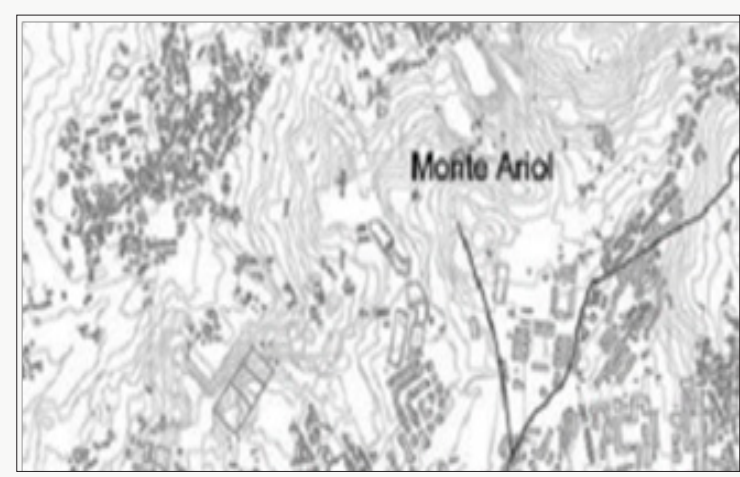

Figure 4: Location of the major hydraulic infrastructures for water supply to Braga medieval city (source: Ribeiro and Martins [1]).

\section{Modern Age}

From the 16th century, Braga as a metropolitan catholic city followed the major European trends associated to the Renaissance ideals, professing the beautification of cities. This boosted the construction of fountains and waterspouts, now with a more sumptuous structure, sculptural decoration and more elaborate architectural design (e.g., the Fountains of Granjinhos, Santiago, Carcova, Castles, and Campo de Santa Ana) (Figure 5). The demographic and economic growth of Braga in the Modern Age has contributed to the increasing need of searching for new local water sources (whether in the urban space or on its surrounding territory). In the archbishopric of Diogo de Sousa (1509-1534), who carried out one of the most important urban interventions in Braga, a special importance to hydraulic works was given, including the construction of fountains and water collection systems, facing the abundance of water running freely over the soil. Several other archbishops intervened in the water supply system of Braga, namely
Rodrigo de Moura Teles (1704-1728), promoting water supply to the Hospital of S Marcos, José de Bragança (1744-1752), ordering the "monumentalization" of the water source complex of Sete Fontes by building "chapels" (round chambers with arched roof) that boast his coat of arms (Figure 6), and Caetano Brandão (1790-1805), which ordered the opening of a gallery around 1804 to supply water to an social institution founded by him (Orphans of S Caetano). The Sete Fontes water supply system, built in the eighteenth century, is composed by: underground branched galleries (eleven of them are still active) collecting spring waters; (covered) stone aqueduct channels with about $3500 \mathrm{~m}$ long for water transportation (Figure 7); cisterns for water storage; waterspouts and fountains for public water distribution. Analyzing the orography of nearby surroundings of Braga, one can easily explain the fact that the major water sources, in the 18th century (Monteariol, Sete Fontes and Gualtar), are located to the north and northeast, where the springs are abundant and the hillsides have a very favorable declivity to its gravity transport into the city In fact, these water sources have 
altitudes ranging between 250 and $300 \mathrm{~m}$ while the main reservoir (Caixa Geral das Águas), for water storage and distribution, should be at a topographic elevation of about $194 \mathrm{~m}$. This situation, allowed avoiding the need of upraised structures for water transport that might justify the curious lack of a monumental aqueduct in Braga (Ribeiro and Martins [4]). On the contrary, the southern land slopes (towards the river East valley), although allowing the natural runoff drainage, it is not favorable for water transport by gravity to the urban center. The water distribution system to the city was held by five different pipes supplying the hospital, convents, stately homes, fountains and waterspouts (AMB [7]). The municipality used an old unit of measure established in function of pipe diameter size for selling water, called "pena", usually converted to an equivalent flow rate of about $600 \mathrm{~L} /$ day. The water buyers (called penistas) had the responsibility to support the cost for water diversion from the public distribution devices to their buildings, and the legal right of maintaining forever to use these water quantities (Figure 8). This baroque waterworks aimed to increase the quality of life of Braga citizens and testifies the advances in knowledge and concepts on hydraulic engineering achieved in Portugal in the Modern Age. A very interesting historic fact is that at the same time a similar water supply system was built by the Portuguese engineers at the Brazilian city of Ouro Preto which still continues in activity.

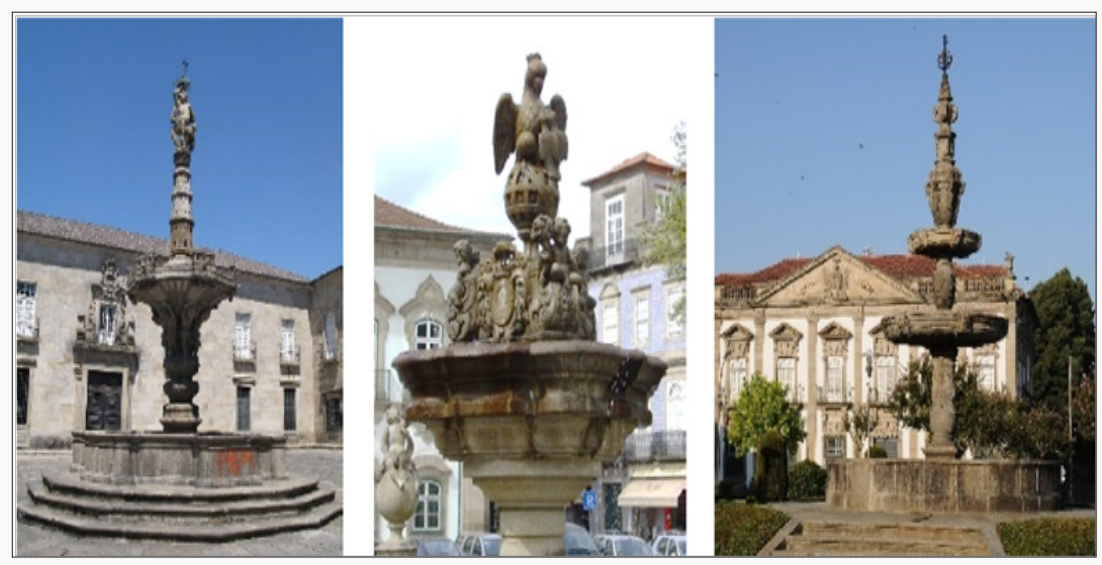

Figure 5: Fountains of Castles (left), Pelicans (centre) and Campo de Santa Ana (right) (Braga, 18th century).

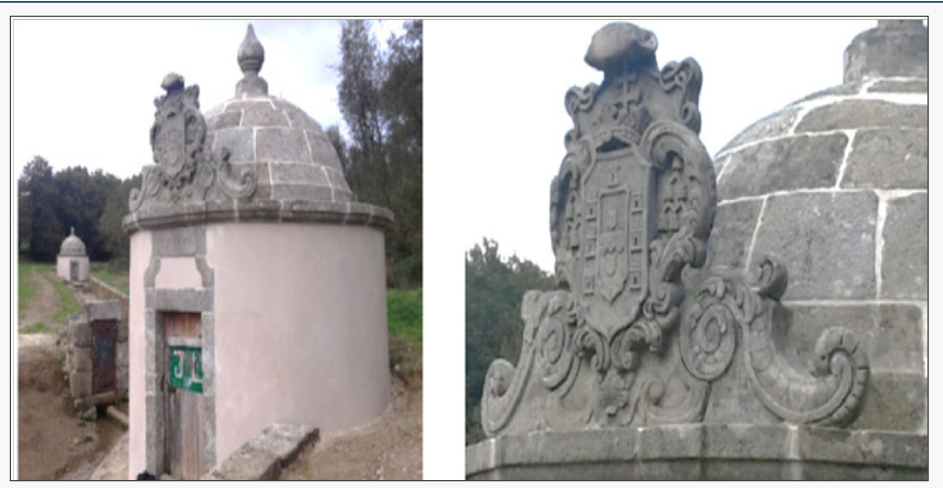

Figure 6: Chapels of the Sete Fontes water source system (Braga, 18th century).
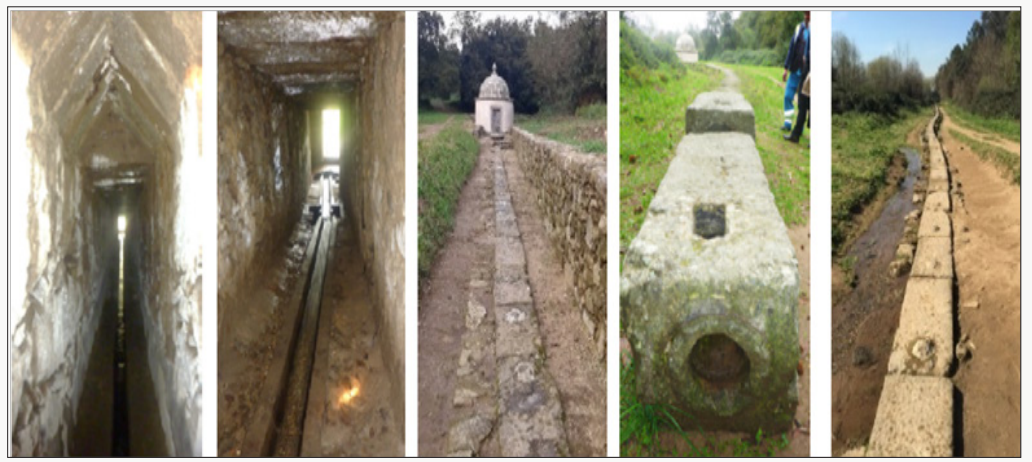

Figure 7: Details of the underground branched galleries and the stone aqueduct channel of Sete Fontes water supply system (Braga, 18th century). 


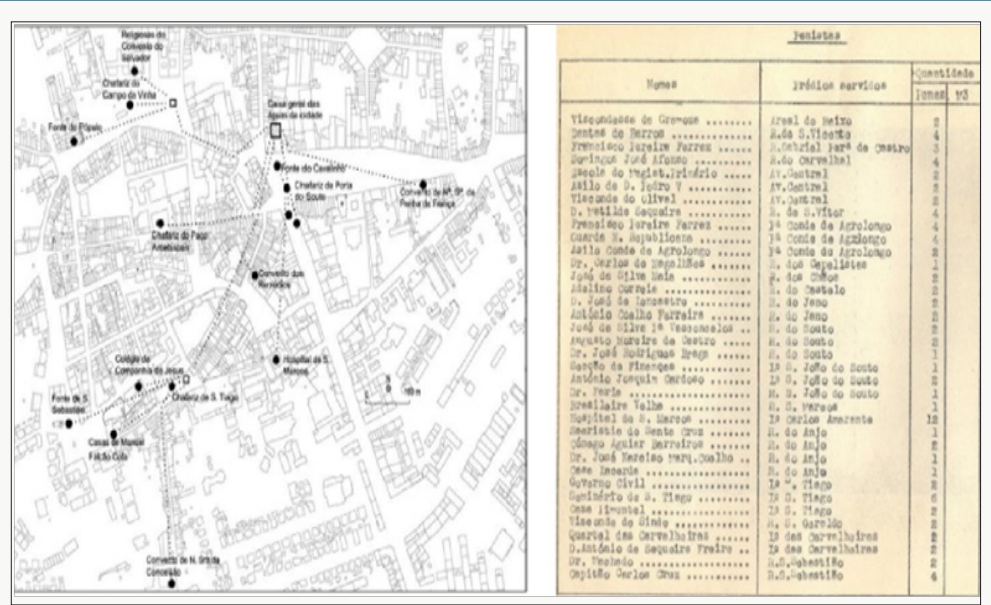

Figure 8: Water distribution network of Braga in the 18th century (left); list of water buyers (penistas) registered in the 20th century (sources: Ribeiro e Martins, 2012; Municipality of Braga).

\section{Contemporary Age}

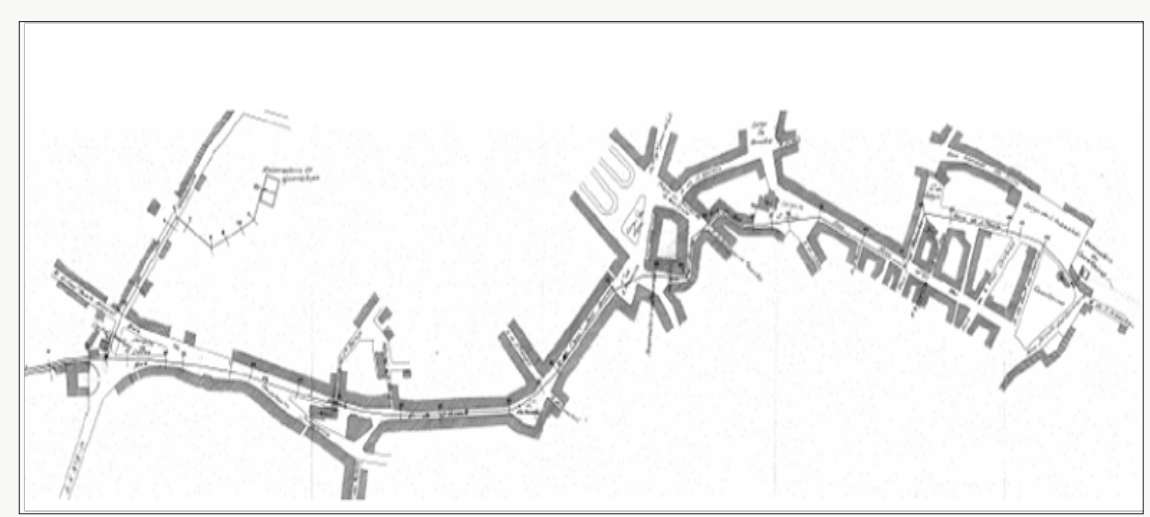

Figure 9: General layout plant of Sete Fontes water supply network (earlier 20th century): stretch of the Braga urban center, between Infias and Cavalheiras squares (source: Municipality of Braga).

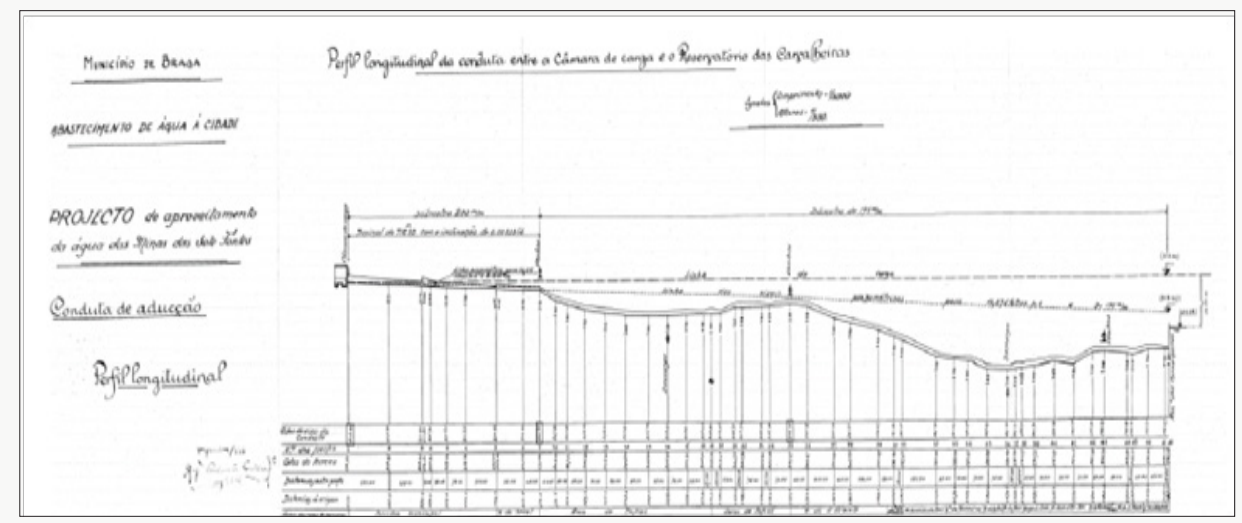

Figure 10: Longitudinal profile of Sete Fontes water supply network (earlier 20th century): stretch between Areal street and Cavalheiras square (source: Municipality of Braga).

Sete Fontes water supply was the main system supplying water to the city of Braga until 1913, when a new abstraction and treatment system was installed in the Cávado river, from where the southern area of the city was served by pumping water to the Guadalupe reservoirs. However, most of the city fountains and waterspouts (and few houses) are still now supplied from this ancient water source system, whose diary productivity, in the year 1934, was estimated on 500 cubic meters. In the third decade of the 20th century some iron pipes were introduced in some of segments of the Sete Fontes water supply network, cast to prevent aquifer losses and facilitate its maintenance, without destroying the ancient infrastructure, and ensuring the continuity of its operation. A study performed by Nascimen to Fonseca (1937), a staff engineer of the Braga Municipality, aiming at the survey and data registration about this ancient water supply system, provided some interesting drawing details on the "Water Use of Sete Fontes Project" in the 
general layout (Figure 9) and longitudinal profiles, namely the pumping station feeding the Guadalupe reservoir (Figure 10). This study presented a proposal establishing new criteria for the changing of "penistas" law rights to use water from Sete Fontes by an equivalent amount of water abstracted from the river Cávado source. It is also revealed that the water of the Sete Fontes galleries was frequently used in dilution of domestic wastewater through its release in manholes equipped with sweeping devices. Since the Sete Fontes water sources system preserves both the original memorial role and their operational functions, its classification as a national monument was deservedly declared on March 25th, 2011. Being this body of water used for drinking water abstraction the official notification also classifies it as a registered protected area. For its cultural significance, preserving its authenticity and integrity, the Sete Fontes water supply system has an unquestionable historical value as a national heritage and constitutes a strategic safe water source legacy.

\section{Sete Fontes: A Safe Water Legacy}

Groundwater is an important source of raw water intended for domestic, agricultural, and industrial uses. Compared to deep groundwater, shallow groundwater is much easier to exploit but more vulnerable to pollutants and its quality is easily influenced by natural water rock interactions and anthropogenic activities. Therefore understanding the hydro-geochemical evolution assumes a key factor for effective control measures and sustainable management policies of groundwater.

\section{Location and Morphology}

The location and path definition of the Sete Fontes water sources reveals a deep knowledge of the surrounding hydrogeological characteristics, since it had been implemented to uptake water existing in this alveolar area situated in a highly contact fractured zone between two types of granite and shale in one of great hydraulic productivity areas around the city of Braga. The Sete Fontes water source system performs, in its fullness, the traditional solutions of hydraulic engineering for water abstraction, transport and distribution from the outskirts underground aquifers. It is a very well designed hydraulic system, including different types of structures: 4 water matrix/"chapels"; 8 intersection stone boxes; 14 water galleries materialized by underground stone aqueducts; and 3 aeration devices (Figure 11) shows the location and morphology of this ancient water source system, which performs a typical hydraulic branched network.

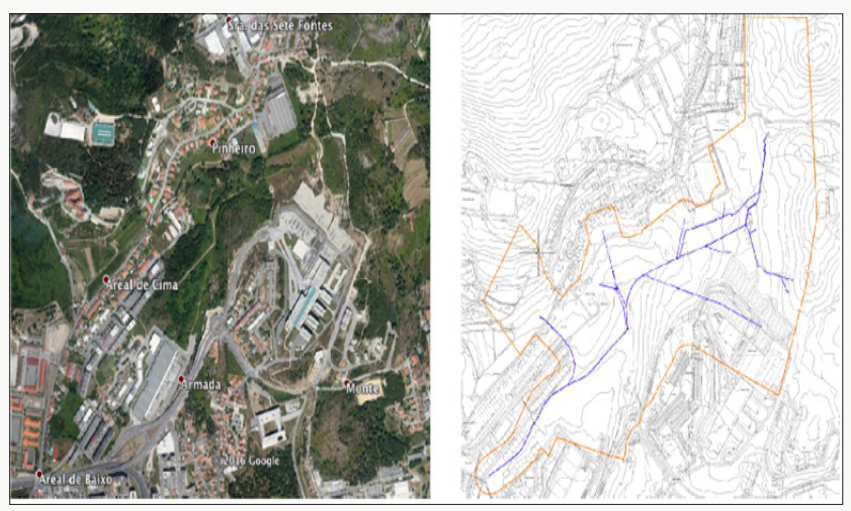

Figure 11: Location and morphological layout of the Sete Fontes water sources system.

\section{Hydraulics and Water Quality}

In order to evaluate the productivity of this system, a summary analysis of the precipitation and the variation of the groundwater levels was done. Results obtained show that the first three months of the hydrological year correspond to the months of highest rainfall, after which there is a gradual decrease in rainfall, reaching the lowest values in the summer months. Despite the period of highest rainfall that takes place in the months of December and January, the piezometric data demonstrate $\backslash$ that the variations in precipitation over the hydrological year are attenuated in the piezometric levels, which have higher values in April and May and the lowest values in September and October. Recently some sampling campaigns were performed (April and October, 2015) in order to determine flow rates and water quality at different locations of the Sete Fontes water source system. Flow rates were measured using an ultrasonic probe and when possible also confirmed by the volumetric method. The main results of these campaigns are presented in
(Figure 12) Water quality from collected samples indicates low concentrations in calcium and magnesium ions which lead to a soft water. Heavy metals and pesticides concentrations were always below the detection limits and, in a few samples, the presence of microorganisms (faecal and total coliform bacteria and intestinal enterococci) was detected, as well as the presence of nitrate in a sample. Based on the overall quality results of the sampling campaign it can be concluded that the Sete Fontes system constitutes a safe water source, and after simple treatment technologies the abstracted water can easily meet the quality standards of water intended for human consumption. It should be noted that in many intersection chapels some water treatment processes (e.g., aeration, gas transfer, sedimentation) are already in place (Figure 13) and in an ingenious way (e.g.: the creation of indoor waterfalls in ventilated manholes for aeration, degasification of undesirable dissolved gases, and iron and manganese removal; the creation of high rotational flows in peripheral settling weirs, located inside the "chapels", to promote suspended solids removal). 


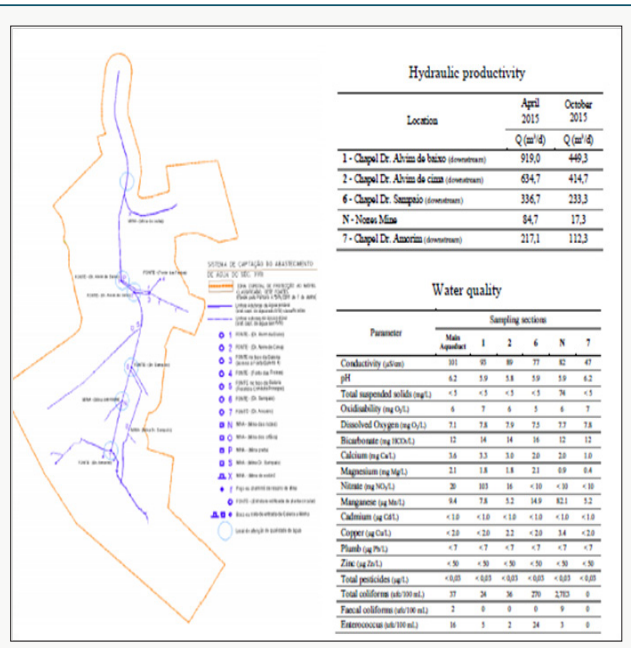

Figure 12: Location of sampling sections. Hydraulic productivity (flow rates) and water quality in the Sete Fontes water source system (April and October, 2015).
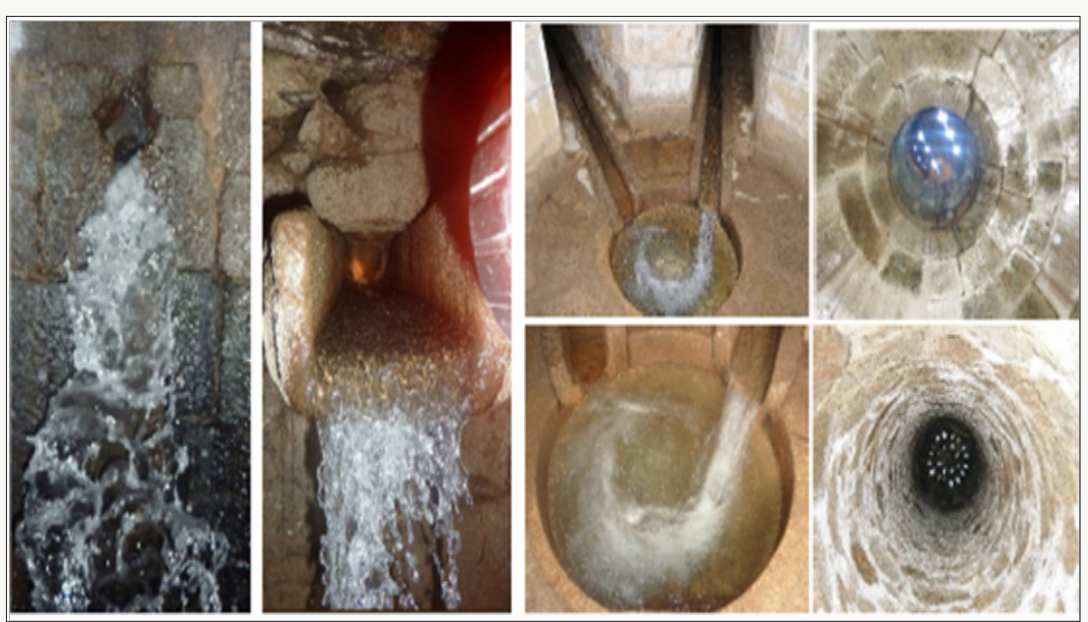

Figure 13: Water treatment processes performed inside the "chapels" (aeration, gas transfer, iron and manganese removal, sedimentation).

\section{Safe Water Sources Scarcity: A Challenge for the Future of Cities}

The quality of life of a city is closely related to the improvement of urban planning and the resilience of infrastructures facing to the challenges of population growth and climate change. In these scenarios, scarcity of water sources will put new threats in providing good and safe drinking water and protecting public health. In the near future one can expect that human development largely will depend on the availability of raw water sources in quality and quantity enough to meet the needs of society. On the other hand water use, land use and polluting human activities in the catchment areas have significant impacts on surface and groundwater, and can highly influence the technological treatment schemes required to ensure that drinking water is safe for human consumption. Currently the drinking water supply system of the city of Braga is based on a single point for abstraction and treatment of surface water from the Cávado river. This means that, for the safety point of view, this municipal system reveals weak resilience to deal with potential river pollution hazards. This situation seems to be even more risky given that this surface water source is located in a small reservoir vulnerable to seasonal processes of eutrophication, which can be intensified in a climate change scenario. Indeed, the increase in average summer temperature and the frequency of extended drought periods may favour the development of cyanobacteria threatening public health. In this context, catchments ancestrally used as water sources and with heritage interest (like the Sete Fontes water system) should be preserved and valued in an effective political commitment and societal support providing strategic water storages for a sustainable management of the urban water cycle in cities of the future.

\section{Acknowledgement}

This work was partially supported by the CTAC-Centre for Centre for Territory, Environment and Construction Project PEst-OE/ECI/UI4047/2014, financed by FCT Foundation for the 
Science and Technology. The authors gratefully acknowledge the contributions of the AGERE-EM the Municipal Company of Braga for Water and Waste.

\section{References}

1. Ribeiro MC, Martins MM (2012) towards the study of the water supply to the city of Braga in Modern Age. The Book of the city of Braga (1737) In: Paths of water Landscapes and uses in the long term, CITCEMTransdisciplinary Research Centre on Culture, Space and Memory 179222.

2. Garrido EA, Mar R, Martins, MM (2008) The Fonte do Ídolo. Analysis, interpretation, and reconstitution of the monument. Bracara Augusta, Escavações arqueológicas, ( $4^{\text {th }}$ Edn). Archaeology Unity of University of Minho, Braga.
3. Carvalho H, Ribeiro, MCF (2009) Bracara Augusta et son territoire. Une approche autour de l'aménagement de l'eau. Colloque International Aménagement et exploitation des zones humides depuis l'Antiquité. Approches comparées en Europe méditerranéenne et continentale, Maison des Sciences de l'Homme, Clermont Ferrand, France.

4. Martins MM, Meireles J, Fontes L, Ribeiro MC, Magalhães F et al. (2012) Water A legacy of Braga Archaeology Unity of University of Minho, Braga.

5. Fontes L, Lemos FS, Cruz M (1998) "Older than" Braga Cathedral. Archaeological Intervention in the Cathedral of Braga: preliminar news. Cadernos de Arqueologia 14-15 série II, 137-164.

6. Marques J $1980 \mathrm{D}$ Fernando da Guerra and the water supply to the city of Braga in the $15^{\text {th }}$ century. Mínia 3(4): 2 série 127-138.

7. AMB (1737) Registration of goods and property, forums and pensions belonging to the senate of the secular chamber of the city of Braga, Book of the City, Archives of the District of Braga 16-25. (c) This work is licensed under Creative

To Submit Your Article Click Here: Submit Article

DOI: $10.32474 /$ TCEIA.2018.02.000129

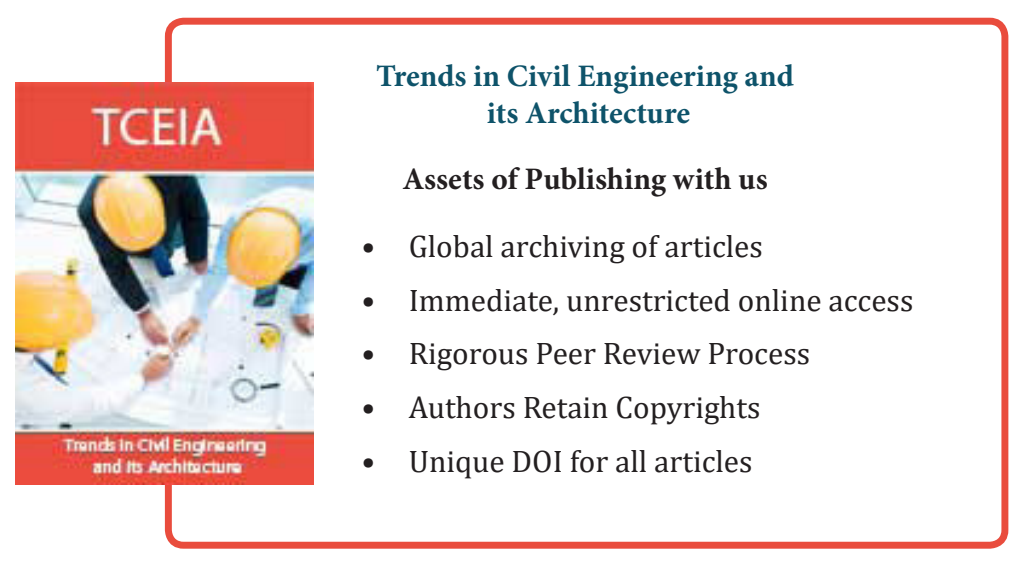

